\title{
Orbital myiasis on recurrent undifferentiated carcinoma in the COVID-19 era: a case report and brief review of the literature
}

\author{
Mansooreh Jamshidian-Tehrani, Kasra Cheraqpour(D, Mohammad Amini, Fahimeh Asadi Amoli and
}

Abolfazl Kasaee*

\begin{abstract}
Background: Myiasis is defined as the infestation of living tissues by Diptera larvae. Ophthalmic involvement occurs in less than $5 \%$ of cases. As the most uncommon type of involvement, orbital myiasis usually affects patients with poor personal hygiene, a low socioeconomic status, a history of surgery, and cancer.

Findings: In January 2020, an 89-year-old man presented to the Oculoplastic Department of Farabi Eye Hospital (Iran) with a history of left-side progressive orbital mass for six months. A large infiltrative mass of the left orbit with extension to the globe, periorbita, and adnexa was remarkable at the presentation, and its appearance suggested malignancy. Our findings persuaded us to perform exenteration and histopathological evaluation which were reported as "undifferentiated carcinoma". Regular follow-up visits were recommended. In June 2020, with a 3month delay, the patient presented with the recurrence of the mass complicated with mobile alive larva.

Examinations revealed numerous maggots crawling out of an ulcerative and foul-smelling lesion. He stated that fear of COVID-19 infection postponed his follow-up visit. The patient underwent immediate mechanical removal of larvae, followed by wide local excision of the mass.

Conclusion: Patients with carcinoma of the adnexal tissues seem to be more prone to myiasis infestation even though it is an uncommon disease. Since COVID-19 is an ongoing pandemic with no end in sight appropriate protocols should be implemented to prevent loss of follow-up in these high risk patients.
\end{abstract}

Keywords: Myiasis, Cancer, COVID-19, Orbital myiasis, Undifferentiated carcinoma

\section{Introduction}

'Myiasis' is derived from 'myia', a Greek word meaning fly [1]. This condition involves the infestation of living tissues by Diptera larvae. Ophthalmomyiasis which is responsible for less than $5 \%$ of cases can be occasionally a life-threatening condition. Crowded places, poor personal hygiene, a low socioeconomic status, surgery, cancer, ischemia, and infection can make patients prone to

\footnotetext{
* Correspondence: az.kasaee@gmail.com

Eye Research Center, Farabi Eye Hospital, Tehran University of Medical Sciences, Qazvin Square, Tehran 1336616351, Iran
}

orbital myiasis [2]. Myiasis is more prevalent in rural regions with a warm climate. Animals such as goats and sheep are natural hosts, whereas humans are invaded accidentally. Myiasis has a destructive behavior, which necessitates early diagnosis and immediate intervention [3].

Limited reports are available in the literature on orbital myiasis. Herein, we report a rare case of orbital myiasis in an old man with a history of orbital tumor that missed his follow-up visits due to the COVID-19 pandemic. Eventually, he presented with the recurrence of the tumor complicated with orbital myiasis.
Springer Open

(c) The Author(s). 2021 Open Access This article is licensed under a Creative Commons Attribution 4.0 International License, which permits use, sharing, adaptation, distribution and reproduction in any medium or format, as long as you give appropriate credit to the original author(s) and the source, provide a link to the Creative Commons licence, and indicate if changes were made. The images or other third party material in this article are included in the article's Creative Commons licence, unless indicated otherwise in a credit line to the material. If material is not included in the article's Creative Commons licence and your intended use is not permitted by statutory regulation or exceeds the permitted use, you will need to obtain permission directly from the copyright holder. To view a copy of this licence, visit http://creativecommons.org/licenses/by/4.0/. 


\section{Case presentation}

In January 2020, an 89-year-old man presented to the Oculoplastic Department of Farabi Eye Hospital with a history of left-side progressive orbital mass for six months. At the presentation, the best-corrected visual acuity (BCVA) of the right and the left eyes was 20/100 and no light perception (NLP), respectively. Examinations of the right eye revealed dermatochalasis and 3+ nuclear sclerosis cataract. Other slit and fundus examinations of the right eye were normal. The examination of the left globe was not possible due to a large infiltrative mass with extension to the globe, periorbita, and adnexa. The patient's history was negative for systemic disease or malignancy. The appearance of the mass was suggestive of malignancy more than other diagnoses. Our findings persuaded us to perform exenteration and histopathological evaluations which were reported as "undifferentiated carcinoma in some foci admixed with sarcomatous stroma (carcinosarcoma), most probably metastatic in origin". An immunohistochemistry (IHC) study showed weakly positive EMA, positive Pan CK, CK-HM, and CK-LM, diffusely positive vimentin, positive CK7, and negative CK20 and S100 in tumoral cells. An oncology consultation was requested to investigate the possible origin of the tumor. To date, all of the investigations were negative.

The patient was asked to visit in March 2020, a date that coincided with the beginning of the COVID-19 epidemic in Iran, leading to quarantine policies and measures. This condition coupled with his poor compliance delayed his follow-up visit. In June 2020, the patient presented after a 3 -month delay with recurrence of his mass complicated by numerous maggots crawling out of an ulcerative and foul-smelling lesion. He stated that fear of the COVID-19 pandemic had caused him to postpone his follow-up visits. The size of the lesion was approximately $10 \times 8 \mathrm{~cm}$. We used a single dose of oral ivermectin prior to surgery to reduce the difficulty of the mechanical removal of the maggots. After oncology consultation, a wide local excision was planned. The specimen for the histopathological study showed interesting findings: undifferentiated carcinoma in some foci in the stroma, with diffuse foreign body-type granulomatous inflammation containing many multinucleated giant cells (Fig. 1). During the surgery, more than 50 maggots were removed from the mass surface (Video 1). In the postoperative period, the patient underwent close observation for monitoring wound infection and removing the missed larvae. Once the wound began to heal, he was discharged.

\section{Discussion}

FW Hope described myiasis for the first time as the infestation of living tissues of vertebrate animals by fly larvae of Diptera called maggots $[4,5]$. Presentations may differ from absence of symptoms to death. The number of invading larvae depends on the genus of Diptera and may vary from one to more than a hundred [6]. Ophthalmic involvement, known as ophthalmomyiasis, occurs in less than $5 \%$ of cases. Ophthalmomyiasis can be classified into external (limited to palpebral and conjunctival tissues), internal (penetration of conjunctiva and sclera with subretinal tissue involvement), and orbital which is a less common but the most severe type [7]. Ophthalmomyiasis usually affects patients on both sides of the age distribution. Poor socioeconomic status, overcrowding, poor sanitation and personal hygiene, alcoholism, debilitating conditions, and mental illness may make the individuals prone to myiasis [8]. The predisposing factors of our case were rural background and low socioeconomic status. We also implicate the COVID-19 pandemic and its psychological effects as stated by the patient. The relatively high prevalence of myiasis in Iran may be justified by the subtropical condition of some provinces and the remarkable number of rural residents in contact with domestic animals. Orbital myiasis usually manifests as unilateral involvement, with itching and crawling sensations are the most common symptoms [9].

Up to 80 species of Diptera can infest human tissues. Dermatobia hominis (human botfly), Cochliomyia hominivorax (screw worm), Hypoderma bovis (ox warble fly), and Oestrus ovis (sheep botfly) are accounted as the most common species [10]. The larvae may invade several parts of

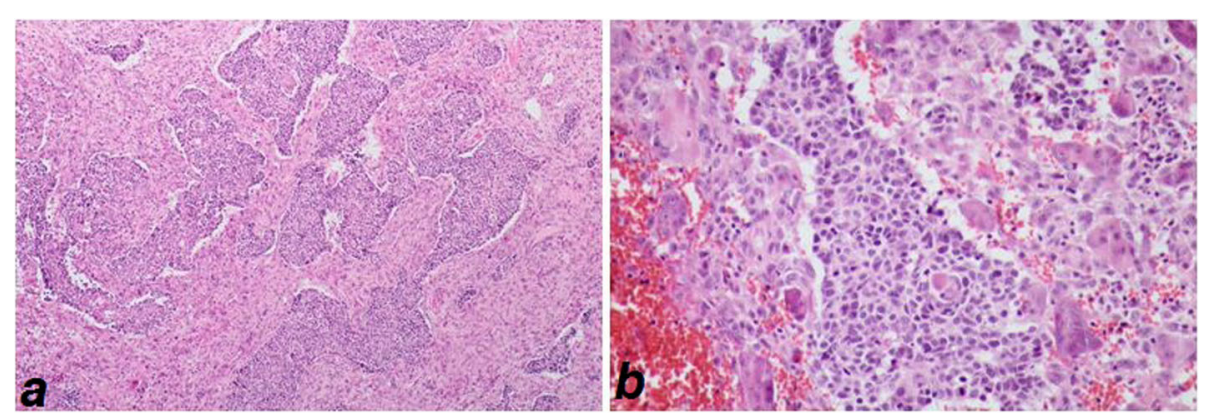

Fig. 1 Islands of undifferentiated carcinoma in the stroma with diffuse foreign body type granulomatous response, H\&E stained $(\times 100,400)$ 
the eye [7]. The Dipteral larvae are photosensitive, and this is the underlying reason for their deep penetration into the tissues [3]. An interesting hypothesis is that adult larvae may select their hosts through visual or olfactory stimuli by attraction to fresh blood. This is usually observed in skin malignancies. Exposed suppurative, necrotic, or hemorrhaging lesions are attractive factors for flies. Hence, the debridement of cellular debris and nonviable necrotic tissue from the wound bed and keeping the wound clean by regular bandage changing can reduce the chance of infection. Previously, skin cancers were implicated as a predisposing factor for orbital myiasis [7].
Among the reported cases of malignancies complicated by orbital myiasis, basal cell carcinoma seems to be more prevalent [2]. Table 1 summarizes similar reports of orbital myiasis on cancers.

The diagnosis is based on clinical findings, and the treatment aims to remove all of the larvae and prevent bacterial superinfection [7]. Brain, orbital, and paranasal sinuses' CT scan/MRI is usually requested to determine the extension of involvement [2]. Solutions such as turpentine oil, liquid paraffin, and petroleum jelly can immobilize the larvae and facilitate the mechanical removal of maggots [3]. The other facilitating options

Table 1 Previous similar reports of orbital myiasis in ophthalmic cancers

\begin{tabular}{|c|c|c|c|c|c|c|}
\hline $\begin{array}{l}\text { No. } \\
\text { [Ref] }\end{array}$ & Age/Sex & Predisposing factors & Eye & Underlying cancer & Management & $\begin{array}{l}\text { Species/ } \\
\text { Number }\end{array}$ \\
\hline $1[7]$ & $85 / F$ & *Malignancy & OD & $\begin{array}{l}\text { Recurrent basal cell } \\
\text { carcinoma of the inferior } \\
\text { eyelid }\end{array}$ & Exenteration plus maxillectomy & $\begin{array}{l}\text { Hypoderma } \\
\text { bovis/ } 71\end{array}$ \\
\hline $2[2]$ & $73 / \mathrm{M}$ & $\begin{array}{l}\text { *Rural background } \\
\text { *Significant bed of } \\
\text { necrosis } \\
\text { *Poor general } \\
\text { condition } \\
\text { *Lack of self-care } \\
\text { *Overcrowded } \\
\text { environment }\end{array}$ & OS & $\begin{array}{l}\text { Basal cell carcinoma of the } \\
\text { lower eyelid with invasion } \\
\text { into the orbit }\end{array}$ & $\begin{array}{l}\text { Manual removal } \\
\text { and debridement followed by antibiotics an } \\
\text { ivermectin }\end{array}$ & $\begin{array}{l}\text { Not mentioned/ } \\
100\end{array}$ \\
\hline $3[11]$ & $98 / \mathrm{M}$ & $\begin{array}{l}\text { *Significant bed of } \\
\text { necrosis } \\
\text { *Poor general } \\
\text { condition *Several } \\
\text { medical comorbidities } \\
\text { *Old ages } \\
\text { *Poor hygiene }\end{array}$ & OD & $\begin{array}{l}\text { Squamous cell carcinoma } \\
\text { of the eyelids }\end{array}$ & $\begin{array}{l}\text { Despite aggressive treatment, the patient died } \\
\text { within } 8 \mathrm{~h} \text {. }\end{array}$ & $\begin{array}{l}\text { Sarcophaga } \\
\text { argyrostoma/ } \\
\text { Not mentioned }\end{array}$ \\
\hline $4[12]$ & $85 / M$ & $\begin{array}{l}\text { *Mental disease } \\
{ }^{*} \text { Dehydration } \\
{ }^{*} \text { Cachexia } \\
{ }^{*} \text { Poor hygiene }\end{array}$ & OS & Basal cell carcinoma & $\begin{array}{l}\text { Manual removal followed by antibiotics and } \\
\text { exenteration. (After surgery, the patient passed } \\
\text { away due to cardiopulmonary failure) }\end{array}$ & $\begin{array}{l}\text { Lucilia sericata/ } \\
\text { About } 70\end{array}$ \\
\hline $5[1]$ & $74 / F$ & *Malignancy & OS & Basal cell carcinoma & $\begin{array}{l}\text { Antibiotics and ivermectin followed by } \\
\text { debridement and enucleation. }\end{array}$ & $\begin{array}{l}\text { Cochliomyia } \\
\text { hominivorax/ } \\
\text { About } 100\end{array}$ \\
\hline $6[13]$ & $24 / \mathrm{M}$ & $\begin{array}{l}\text { *Significant bed of } \\
\text { necrosis } \\
\text { *Poor hygiene } \\
\text { *Low socioeconomic } \\
\text { status } \\
\text { *Defective immunity } \\
\text { due to xeroderma } \\
\text { pigmentosa }\end{array}$ & OS & Squamous cell carcinoma & Exenteration & $\begin{array}{l}\text { Calliphoridae/ } \\
\text { Not mentioned }\end{array}$ \\
\hline $7[14]$ & $83 / \mathrm{M}$ & *Malignancy & OS & Basal cell carcinoma & Manual removal followed by antibiotics & $\begin{array}{l}\text { Not mentioned/ } \\
\text { Not mentioned }\end{array}$ \\
\hline $8[15]$ & $80 / \mathrm{M}$ & *Malignancy & OD & $\begin{array}{l}\text { Squamous cell carcinoma } \\
\text { of the eyelid }\end{array}$ & Manual removal followed by antibiotics & $\begin{array}{l}\text { Cochliomyia } \\
\text { hominivorax/ } \\
\text { Not mentioned }\end{array}$ \\
\hline $9[8]$ & $50 / \mathrm{M}$ & *Malignancy & OS & Basal cell carcinoma & Manual removal followed by exenteration & $\begin{array}{l}\text { Phylum } \\
\text { Arthropoda/ Not } \\
\text { mentioned }\end{array}$ \\
\hline $10[16]$ & $\begin{array}{l}\text { 2/ Not } \\
\text { mentioned }\end{array}$ & $\begin{array}{l}\text { *Significant bed of } \\
\text { necrosis } \\
\text { *Lack of self care and } \\
\text { communication }\end{array}$ & OD & Retinoblastoma & $\begin{array}{l}\text { Manual removal followed by antibiotics, } \\
\text { radiotherapy and chemotherapy }\end{array}$ & $\begin{array}{l}\text { Not mentioned/ } \\
\text { Not mentioned }\end{array}$ \\
\hline
\end{tabular}


include hydrogen peroxide and isopropyl alcohol with larvicidal properties [3]. Recently, ivermectin has been used for treatment, and its use prior to the surgery has been recommended to facilitate the mechanical removal of the maggots. In fact, much of the experience of the use of ivermectin for myiasis treatment comes from veterinary medicine. In other words, ivermectin is an offlabel option in many countries since no standard study has been conducted on its use. Although a single oral dose of ivermectin is the most commonly prescribed form of usage, the role of continuing this agent after surgical debridement to reduce the chance of recurrence is still not clear. As for surgical management, options vary from saving the globe approach through surgical removal of larvae to aggressive surgeries such as exenteration [2]. Note that the mechanical removal of the flies may be required in more than one session [3]. The chance of intracranial invasion due to the proximity of the globe to the brain highlights the significance of orbital myiasis, differentiating it from the infestation of other sites. Therefore, exenteration is recommended in cases with orbital apex involvement.

\section{Conclusion}

Patients with carcinoma of the adnexal tissues seem to be more prone to myiasis infestation even though it is an uncommon disease. Since COVID-19 is an ongoing pandemic with no end in sight appropriate protocols should be implemented to prevent loss of follow-up in these high risk patients.

\section{Abbreviations}

BCVA: Best-corrected visual acuity; NLP: No light perception; IHC: Immunohistochemistry; CT scan: Computed tomography scan; MRI: Magnetic resonance imaging; M: Male; F: Female; OD: Oculus dexter (right eye); OS: Oculus sinister (left eye)

\section{Supplementary Information}

The online version contains supplementary material available at https://doi. org/10.1186/s12348-021-00271-1.

Additional file 1: Video 1. Showing numerous maggots crawling out of an ulcerative lesion with necrotic surface.

\section{Acknowledgments}

None.

\section{Authors' contributions}

MJT and AK visited the patient, performed treatment and collected the patient information. KC wrote the manuscript. MA, FAA, and KC performed critical revisions on manuscript. All authors read and approved final manuscript.

\section{Funding}

None.

\section{Availability of data and materials}

The data of current case report are available from the corresponding author on reasonable request.

\section{Declarations}

Ethics approval and consent to participate

Ethics approval is not required for publishing of case reports in our institution. Informed consent was obtained from all individual participants included in the study.

\section{Consent for publication}

Written consent was taken from the patient for publication of this report and accompanying images and videos.

\section{Competing interests}

The authors declare that they have no competing interests.

Received: 29 March 2021 Accepted: 4 October 2021

Published online: 20 November 2021

References

1. Khardenavis SJ, Kulkarni S, Khardenavis V, Deshpande A (2018) Case report: Ophthalmomyiasis in a case of basal cell carcinoma of eyelid. BMJ case reports 2018

2. Pandey TR, Shrestha GB, Shah DN (2016) A case of orbital myiasis in recurrent eyelid basal cell carcinoma invasive into the orbit. Case reports in ophthalmological medicine 2016:1-4. https://doi.org/10.1155/2016/2904346

3. Kalamkar C, Radke N, Mukherjee A (2016) Orbital myiasis in eviscerated socket and review of literature. Orbital myiasis in eviscerated socket and review of literature Case Reports:2016. https://doi.org/10.1136/bcr-2016-215361

4. Kersten RC, Shoukrey NM, Tabbara KF (1986) Orbital myiasis. Ophthalmology 93(9):1228-1232. https://doi.org/10.1016/S0161-6420(86)33592-9

5. Baliga MJ, Davis P, Rai P, Rajasekhar V (2001) Orbital myiasis: a case report. Int J Oral Maxillofac Surg 30(1):83-84. https://doi.org/10.1054/ijom.2000.0007

6. Cordero-Moreno R (1973) Etiologic factors in tropical eye diseases. Am J Ophthalmol 75(3):349-364. https://doi.org/10.1016/0002-9394(73)91144-6

7. Caça I, Ünlü K, Cakmak SS, Bilek K, Yıldırım BŞ, Ünlü G (2003) Orbital myiasis: case report. Jpn J Ophthalmol 47(4):412-414. https://doi.org/10.1016/S00215155(03)00077-7

8. Raina UK, Gupta M, Kumar V, Ghosh B, Sood R, Bodh S (2009) Orbital myiasis in a case of invasive basal cell carcinoma. Oman journal of ophthalmology 2(1):41-42. https://doi.org/10.4103/0974-620X.48422

9. Huang Y-L, Liu L, Liang H, He J, Chen J, Liang Q-W, Jiang ZY, He JF, Huang ML, du Y (2020) Orbital myiasis: a case report and literature review. Medicine 99(4):e18879. https://doi.org/10.1097/MD.0000000000018879

10. Denion E, Dalens PH, Couppie P, Aznar C, Sainte-Marie D, Carme B et al (2004) External ophthalmomyiasis caused by Dermatobia hominis. A retrospective study of nine cases and a review of the literature. Acta Ophthalmol Scand 82(5):576-584. https://doi.org/10.1111/j.1600-0420.2004.00315.x

11. Ayalon A, Yehezkeli V, Paitan Y, Szpila K, Mumcuoglu KY, Moisseiev E (2020) Massive Orbital Myiasis Caused by Sarcophaga argyrostoma Complicating Eyelid Malignancy Case Reports in Ophthalmological Medicine:2020

12. Abalo-Lojo JM, Lopez-Valladares MJ, Llovo J, Garcia A, Gonzalez F (2009) Palpebro-orbital Myiasis in a Patient with Basal Cell Carcinoma. In: Palpebroorbital myiasis in a patient with basal cell carcinoma. SAGE Publications Sage UK, London, England

13. Kamal S, Bodh SA, Kumar S, Goel R (2012) Orbital myiasis complicating squamous cell carcinoma in xeroderma pigmentosum. Orbit 31(2):137-139. https://doi.org/10.3109/01676830.2011.638103

14. Sardesai $\vee$, Omchery A, Trasi S (2014) Ocular myiasis with basal cell carcinoma. Indian Journal of Dermatology 59(3):308-309. https://doi.org/1 0.4103/0019-5154.131431

15. Khurana S, Biswal M, Bhatti H, Pandav S, Gupta A, Chatterjee S, Lyngdoh WV, Malla N (2010) Ophthalmomyiasis: three cases from North India. Indian J Med Microbiol 28(3):257-261. https://doi.org/10.4103/0255-0857.66490

16. Karkhanawala MM, Patel UJ, Patel M, Thakkar HH (2018) Orbital Myiasis: an unusual presentation of retinoblastoma. The Official Scientific Journal of Delhi Ophthalmological Society 29(2):70-72. https://doi.org/10.7869/djo.405

\section{Publisher's Note}

Springer Nature remains neutral with regard to jurisdictional claims in published maps and institutional affiliations. 